\title{
Leadership Style in Character Education at The Darussalam Gontor Islamic Boarding
}

\author{
M. Ihsan Dacholfany \\ Muhammadiyah University of Metro Lampung \\ mihsandacholfany@yahoo.com
}

\begin{abstract}
Pesantren (Islamic Boarding) is the oldest educational institution in Indonesia which has a role in character education. The main purpose of this study was to understand leadership style of teachers (clerics) in character education as well as the process to produce competent believers. Religio-paternalistic leadership is based on the value of total admission of religious and educational methods, with emphasis on the application of knowledge resulting believers' faith and fear of Allah guided by the Qur'an and Sunnah. To obtain data, the author employed interview, observation and documenter. The Darussalam Gontor Islamic Boarding School in East Java was the field-site of this research.

Pondok Pesantren merupakan lembaga pendidikan paling tua di Indonesia memegang peran penting dan strategis dalam pendidikan karakter. Artikel ini bertujuan untuk memahami gaya kepemimpinan (kyai) dalam pendidikan karakter serta prosesnya sehingga dapat menghasilkan mu'min yang kompeten. Kepemimpinan religiopaternalistic didasarkan atas nilai-nilai keagamaan dan metode pendidikan totalitas. Totalitas dalam mengutamakan pengaplikasian semua ilmu pengetahuan sehingga menghasilkan mukmin yang beriman dan bertakwa kepada Allah Swt. dengan berpedoman pada al-Qur'an dan as-Sunnah. Penulis focus pada pendidikan karakter berbasis pesantren. Metode pengumpulan data yang digunakan dalam penelitian ini adalah wawancara, observasi dan documenter. Lokasi penelitian di Pondok Pesantren Darussalam Gontor, Jawa Timur Indonesia
\end{abstract}

\section{Keywords: Leadership; Education; Character}




\section{A. Intruduction}

Education is a basic capital in the construction of which will determine the progress and development of a nation, because with education, potential and resources of each individual can be developed, is expected to built up human personality conscious of its responsibility as an individual, being moral, social beings and creatures of religion so it has a good character and dignified, then education must be a top priority in the development of Indonesia better, advanced and developed in the future. According Langeveld, that education is every effort, influence, protection and assistance given to children drawn to the maturation of the child, or more precisely to help children to be quite capably carry out the task his own life. The influence of the arrival of an adult (or created by adults such as school, books, round of daily life, and so on) and addressed to minors ${ }^{1}$.

According Kyai Abdullah Syukri Zarkasyi that dormitory at boarding school system supports the creation of integration tri-education centers; schools (formal), family (informal) and community (nonformal). In a boarding school life, these three elements can be combined. They are family caregivers, teachers, and students themselves. They live in boarding schools run by the schools themselves. The dormitory system strongly supports the implementation of the curriculum for twenty-four hours. Because three integrated education centers have advantages over non-boarding: First, the ability of efficient coordination since all functionaries are in college. Secondly, fostering the ability of students from environmental influences. Third, the mosque serves as a center of animating, and clerics as a central figure. It can be said boarding is a miniature of life, it takes place in a wide range of activities that require students to move and encourage him to learn to live and to live in a pluralistic environment. ${ }^{2}$ Then the background boarding school education has an important role in growing and developing the values of character education in Islamic behavior. Boarding excellence lies in the principle of 'humanizing' in the learning process and incorporate three education

${ }^{1}$ Hasbullah. Basic Education. Jakarta. Publisher: PT Persada Raja Grafindo, 2005, p.14

2 Abdullah Syukri Zarkasyi, Gontor and Updates education schools, (Jakarta: Rajagrafindo, 2005), p.24 
center in an environment that is deliberately engineered to have foster his students to have a strong character, both from the scientific side of religious, public and everyday behavior. Character education starts from the leadership of clerics, while the clerics leadership style is expected to change the mindset and behavior to practice the values of character education. Thus, the growth of Islamic boarding school is highly dependent on personal ability leaders ${ }^{3}$.

Existence Islamic boarding school led by clerics as a leader is very unique to be studied, because when see from the duties and functions of clerics who do not just draw up the curriculum, make the evaluation system and arrange the order of the institution, but also set the values of character education, as well as builder residents of boarding schools and the community. Therefore leader/clerics are required to have the wisdom and insight, skilled in the science of religion and can be good role models, even where clerics often associated with the phenomenon of power that is supernatural, in which the figure of clerics regarded as the heir treatise prophetic, so that the existence of clerics hardly be associated with someone who has a close relationship with $\mathrm{God}^{4}$, then the process of character education in schools needs to be continuous development and improvement, good character building and strategy clerics manage schools so that they can compete positively or compete least able to pursue backwardness with guided by the "old guard and still remain viable and take a new one, but better".

Based on the information above, the research and writing of the " style leader in character education in pesantren (islamic boarding) darussalam gontor" that has been developed is very important and interesting to study, so it can be applied and developed in Pesantren (islamic boarding) other parts of Indonesia and even abroad.

Boarding is one of the educational institutions are expected to build an Islamic character and produce graduates who have the competence deal with change at the present time. The main factors causing the roll mat boarding school because leader died. Boarding survival depends heavily on its ability to prepare the next generation of capable and qualified at the time abandoned leaders and have knowledge of

${ }^{3}$ Zamakhsyari Dhofier, Tradisi Islamic Boarding Worldview leaders (Jakarta: LP3ES. 1994), p. 14

${ }^{4}$ Nurcholis Madjid, Cubicles Islamic Boarding School: A Portrait Journey, (Jakarta: Paramadina, 1997), p.133. 
management schools and national education standards are met (SNP). Below is a chart of Figure 1 Problem formulation of this research and figure 1 of the Mindset of the study:

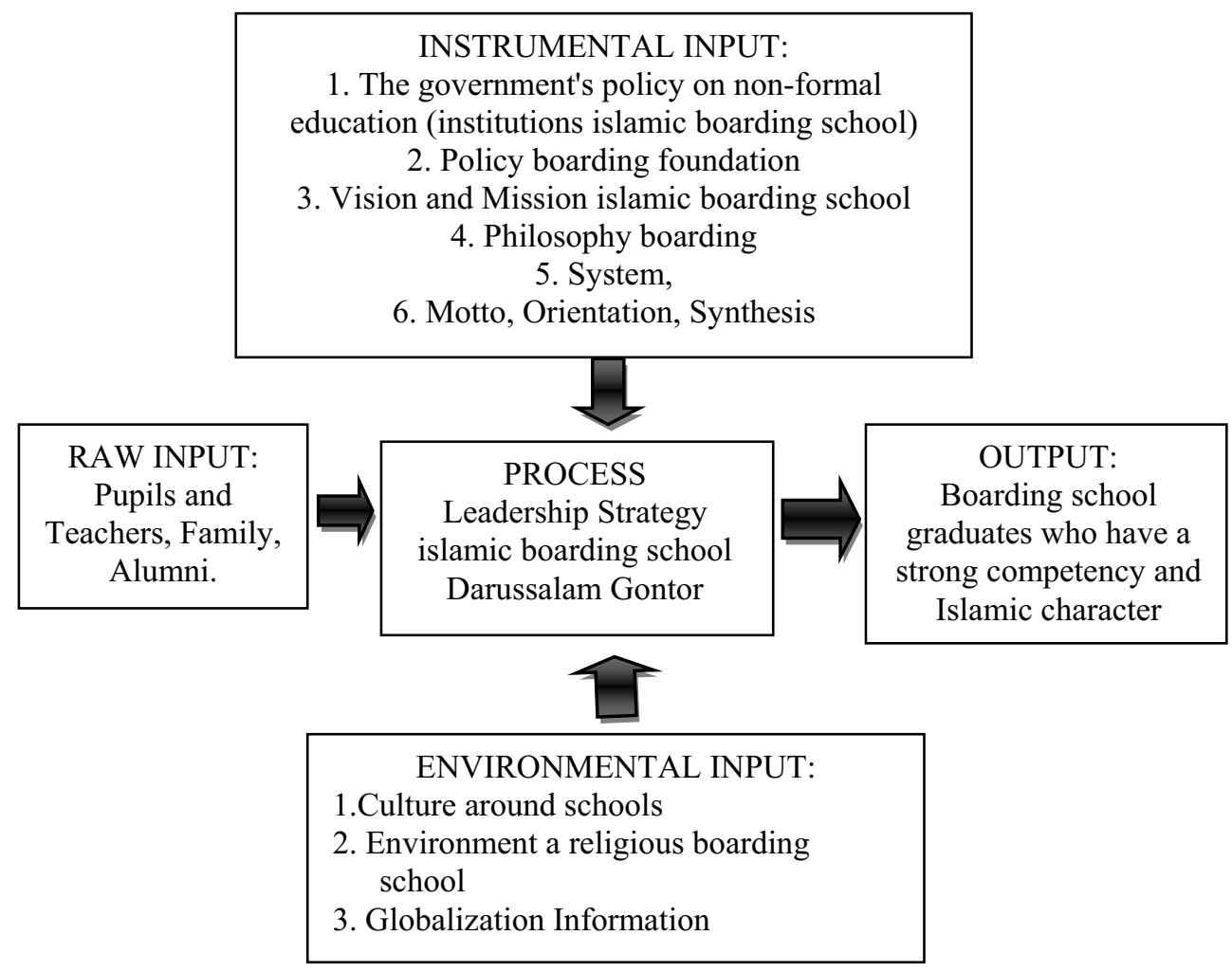

Gambar 1.1 


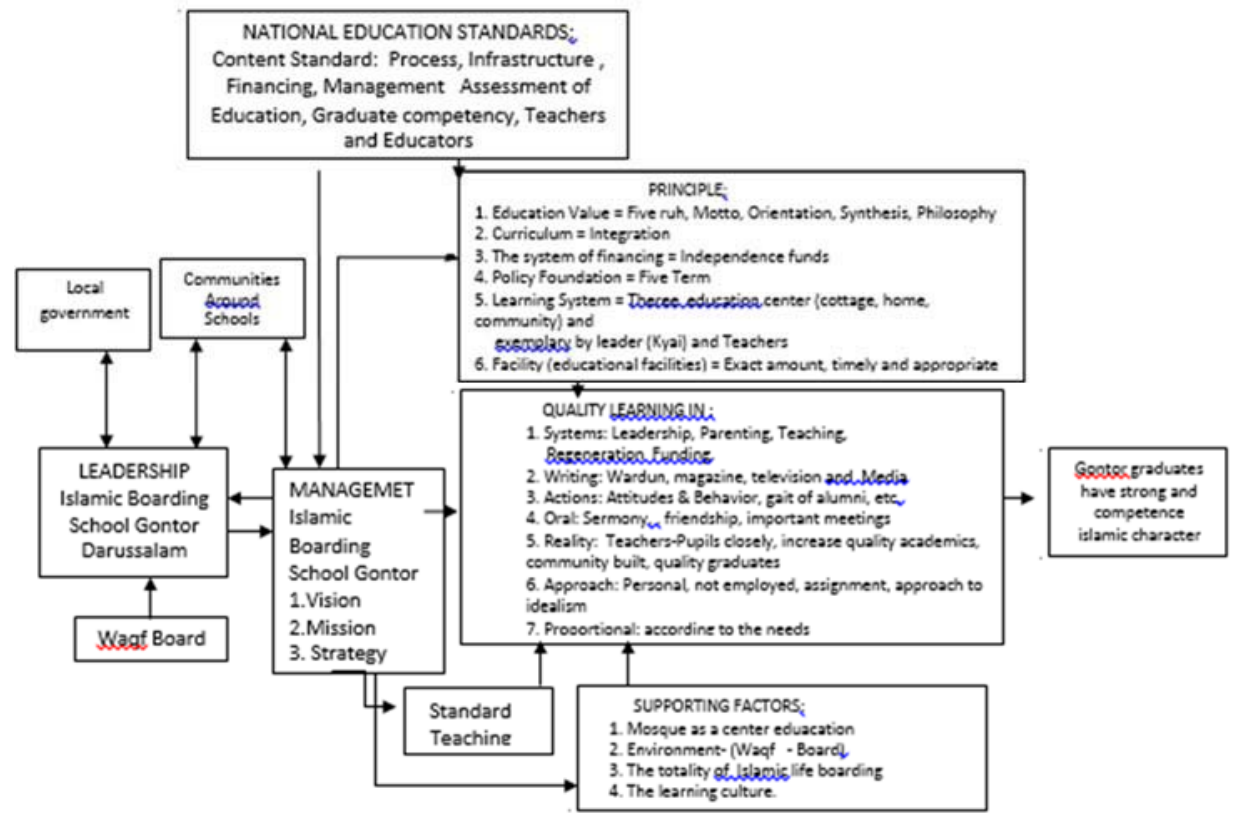

Figure 2. Conceptual Framework Studies " Style Leader in character education in Pesantren (Islamic boarding school) Darussalam Gontor East Java, Indonesia

Darussalam Gontor, East Java.

With the National Education Standards is the vision, mission and strategy management in boarding school education is tailored to the demands of the times that is still based on the teachings of Islam.

Base on the theories above, the formulation of the research problems on Pesantren (islamic boarding) Gontor Darussalam are as follow:

1. What leadership style strategy developed by clerics in implementing character education students?

2. What are the problems encountered in implementing character education Kyai?

3. What efforts are made clerics in implementing character education? 
The purpose of this research is to know the leadership style strategy clerics, the methods used, problems encountered and efforts in character education programs in islamic boarding school Darussalam Gontor. This research article is expected to be useful in generating some postulate and theory that can be used as a reference for researchers, specifically examine the character education in Islamic boarding school Gontor, in order to be useful as the development of theories leadership clerics. In addition, researchers have relevance to the future character education in academics or researchers so that the future bore theoretical framework that is more up to date, relevant to the development of public life in accordance with the development of the concept of character education in Indonesia so as to make any output Islamic educational institutions can produce human that have competent, Islamic character, intellectual, moral, noble. The researcher hope that the study is useful for the heads of educational institutions, educators, officials of the relevant departments, it is also useful to invoke the graduates and educational institutions similarly, as well as for further research.

\section{B. History of islamic boarding school Darussalam Gontor}

Islamic boarding school Darussalam Gontor was established on Monday, 12 Rabi al-Awwal 1345/20 September 1926 by three brothers, namely Kyai Ahmad Sahal, Kyai Zainuddin Fannani and Kyai Imam Zarkasyi, they are three brothers better known as "Trimurti". Based on session Waqf Board in 1985, the history of Islamic boarding school leaders Gontor does not have family or founder, so the leadership could be lifted from the teachers and students of senior discretion limbs and was able to become a leader, such as Kyai Shoiman Lukmanul Judge Kyai Imam and Kyai Syamsul Hadi Abdan are senior students and teachers.

\section{Discussion Problems}

1.Strategy Leadership style Pesantren (islamic boarding) Darussalam Gontor in Developing character Pupils, Kyai (clerics) leadership style strategy is religio-paternalistic leadership style mean interaction force between the clerics with the students or subordinates based on religious values are anchored in the leadership style of the Prophet Muhammad, peace be upon him and has a charismatic and always invoke the guidance instructions and Allah. It can be seem in Figure 1 Implementation of the 
strategy totality leadership of Pesantren (islamic boarding) Darussalam Gontor in character education below.

So if attention to the picture above, it appears that the implementation of leadership style clerics, in character education, in total touch himself and his family, a model for the Pesantren (islamic boarding) he led, implemented in the life of the surrounding community, and useful in the world of work, political parties, government and abroad and various educational institutions. All of it as the embodiment of the relationship to God.

According to Nur Hadi Ihsan, that clerics not only nurture students, but we, the teachers, administrators, rearing up on the wives also nurtured, educated in various meetings, even family welfare is also a concern clerics, for example, sometimes he asks how the savings we have, and sometimes visited the house chaplain just to see the possibilities in need of repair. The example above shows religious scholars give to the Pesantren (islamic boarding) community to a commitment to the values that underlie the behavior of boarding ${ }^{5}$

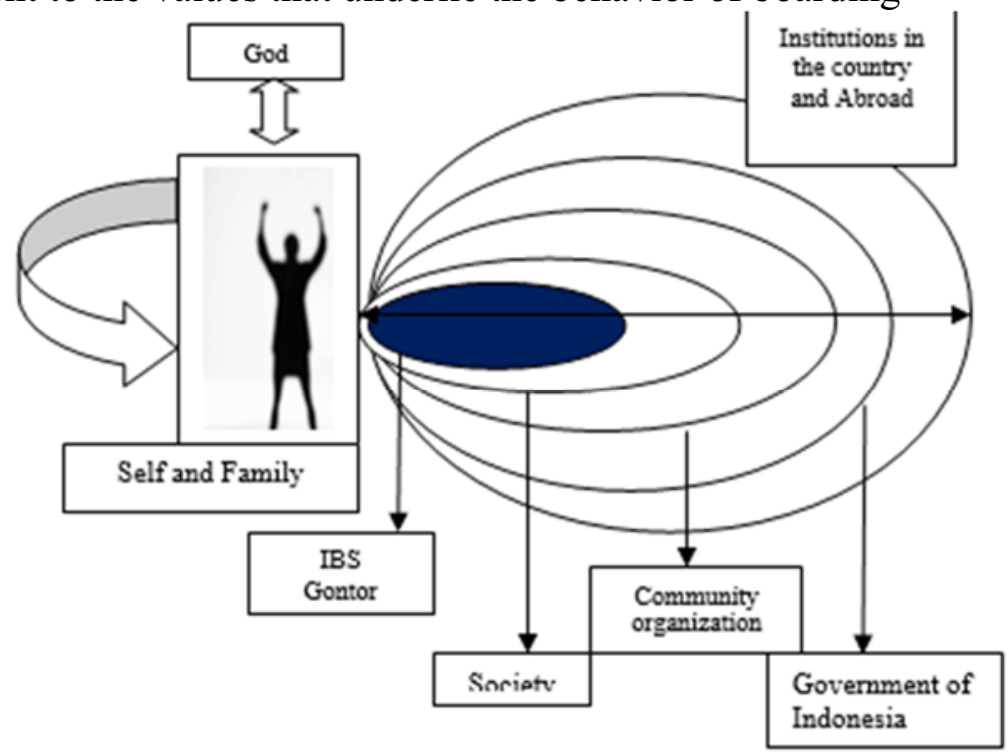

Figure 3 in Scheme Flow Transformation Method

5 Interview with Vice Director teacher Pesantren (Islamic Boarding) Gontor, home offices teacher, dated August 14, 2011 
So if look at to the picture above, it appears that the implementation of leadership style clerics, in character education, in total touch himself and his family, a model for the boarding school he leds implemented in the life of the surrounding community, and connected in the working world, political parties, government and abroad and various educational institutions. All of it as the embodiment of the relationship to God. Character Education with Values Pesantren (islamic boarding) Darussalam Gontor at Figure 4.

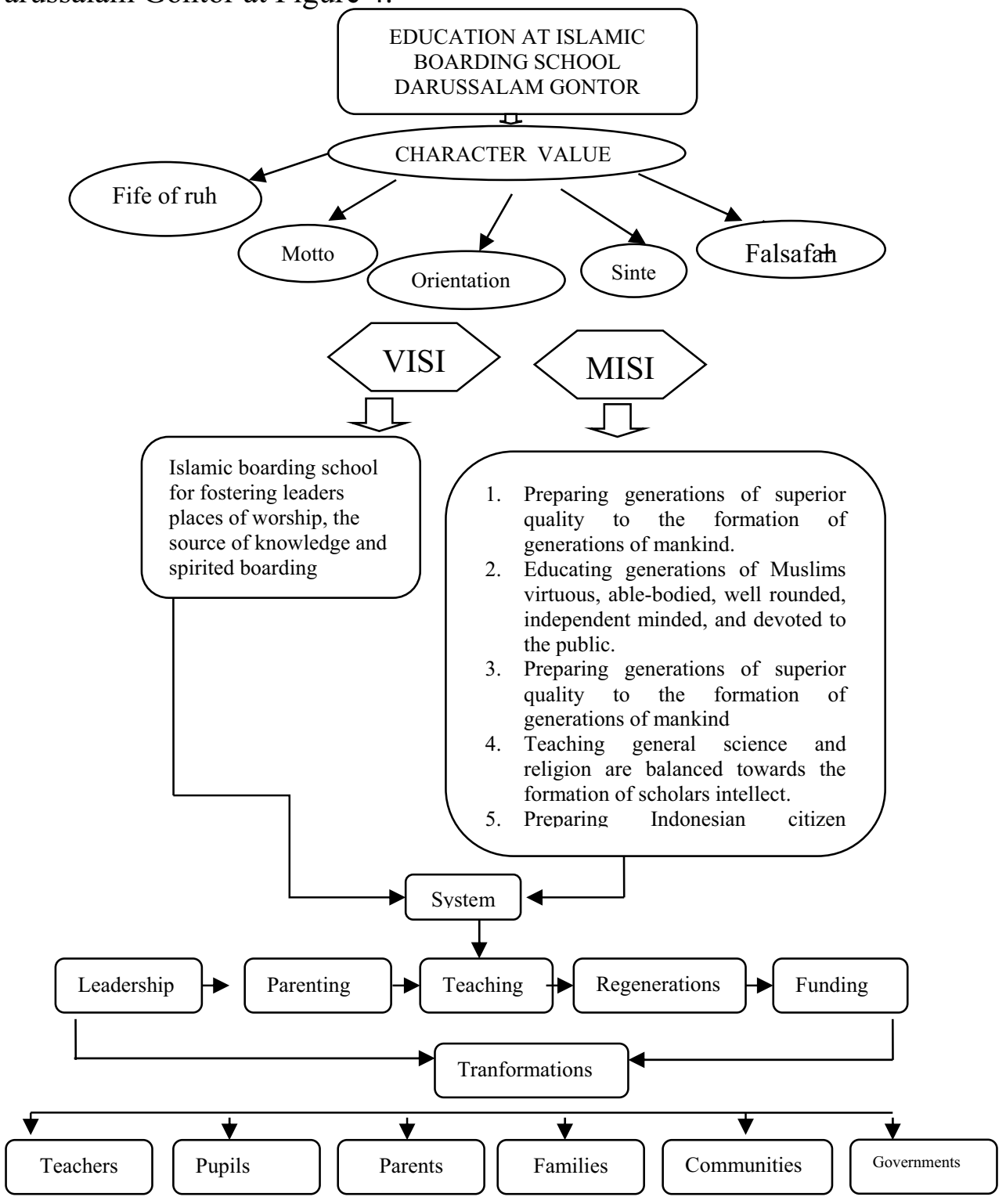




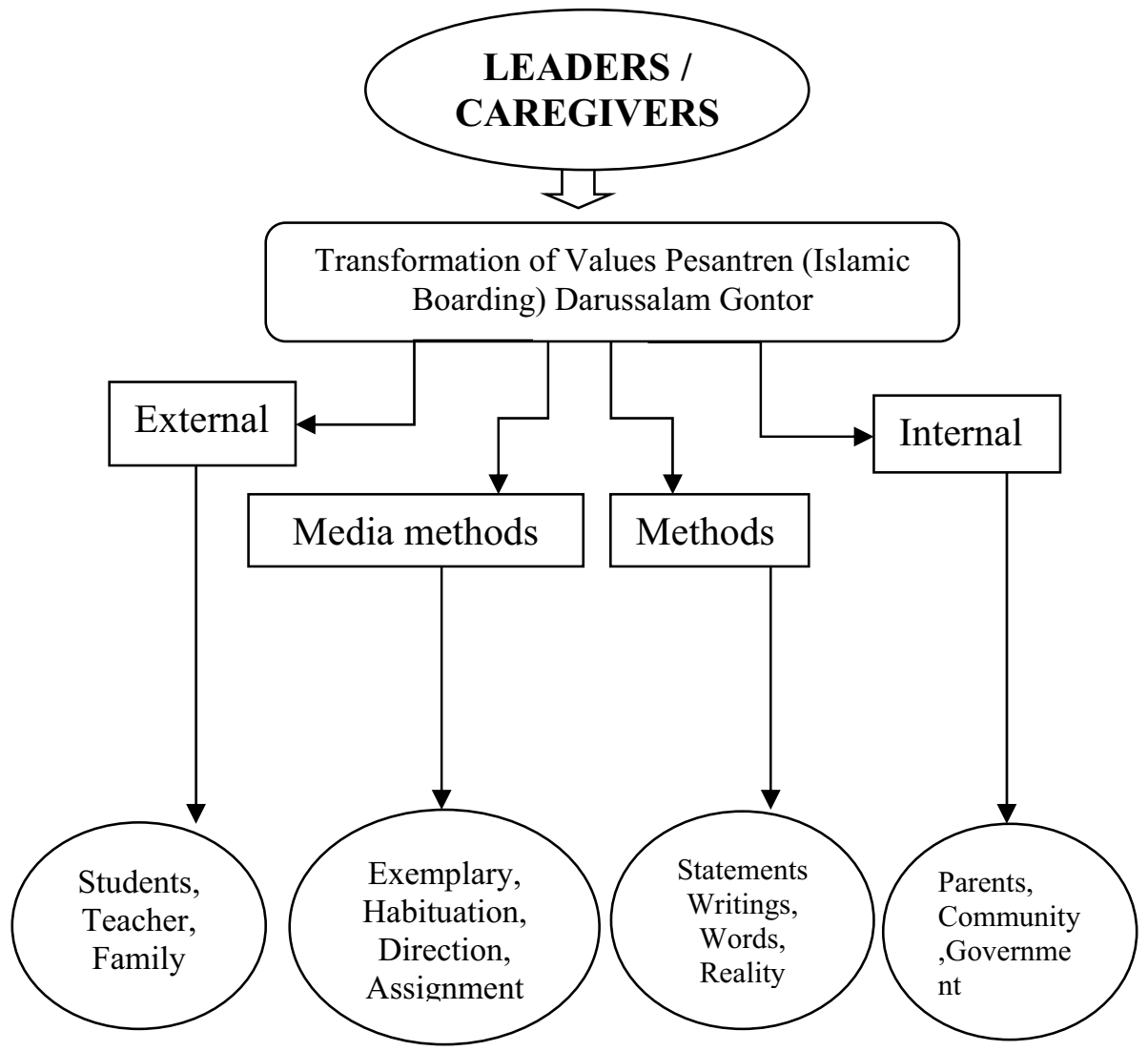

Figure 5 explains Leader or clerics dimension very wide, so the positive things this gives direct and indirect influence on the quality of the internal management of the boarding school education, as well as an effect on the quality of graduates of islamic boarding school students Gontor. Strategy totality leadership style is manifested in the form of leadership role as a visionary, communicator, and motivator ${ }^{6}$,

To achieve the goal of educational character, this agency implementing an education strategy in which the life of the lodge with all its totality a medium of learning and education itself, the elements forming the values of Pesantren (islamic boarding), both human and infrastructure both physical and non-physical, directed to support the creation of an educational environment so that as a whole is designed for the benefit of the community-based character education, so that all has

6 The Guidebook Pesantren (Islamic Boarding), Ponorogo Trimurti Press: 1998, p. 23 
been heard, seen, felt, done, and experienced by the students and even the whole of the schools is intended to achieve educational goals.

All programs are by no means a process that is deliberately created and is set to run the next best to sustain the principle of independence of the Islamic Boarding School that should be realized by all members of the community in the schools of religious scholars, teachers, professors, the students and families. Besides sustain educational and teaching activities, some of these institutions, aimed at improving the welfare of the family and teachers.

In this way, the cost of teachers' welfare is not taken from the tuition the students. Besides donations student development also all the results of the business units that are managed under the auspices boarding school student organizations are not allowed to be used as a source of income for the welfare of clerics or teachers in this lodge. "What is sought by the teachers back to teachers, and what is paid out and managed by the students returned to the students. So there is no term students who pay the teacher".

Based on the results of the study, this concept becomes important to ensure the application of discipline that aims to build the character of students with enough life skills and strengthen the values autonomy.

This accordance with the institutional philosophy conceptualized by the founder of schools, that: "The Pesantren (islamic boarding) is a field of struggle, not a place to make a living," Pesantren (islamic boarding) lives it and do not make a living from the Islamic Boarding School".

The clerics/leader have always warned that "once lived a meaningful life" Life would be meaningful if the benefit of others. Thus the greater the benefit of a person to another person, the greater the value of the good of the "best of man is most beneficial for one another", with different expressions "_meritorious or be servive but do not ask for services". That is, the benefit thing was done previously for benefit the people, then let those who would vote, not vice versa. as word of God which reads:

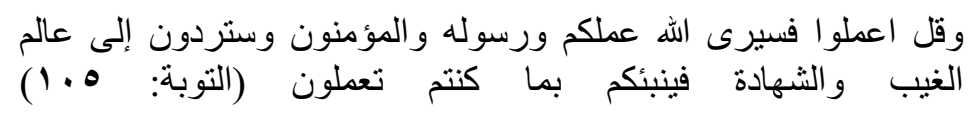

"And Say:" Work ye, then Allah and His messenger and 
the believers will see your work, and you will be returned to (Allah) who knows the will of the unseen and the real, and preached unto you what you have you do ".) QS, At-Tawbah: 105).

How important the awareness of the values of this life so that the benefit derived by each of the students who are studying to be determined how much awareness of the meaning, of the learning process for awareness, for it also your profits ${ }^{7}$. "Under this Figure 6 in Scheme/Figure 6 Education Process in the Pesantren (islamic boarding) Darussalam Gontor.

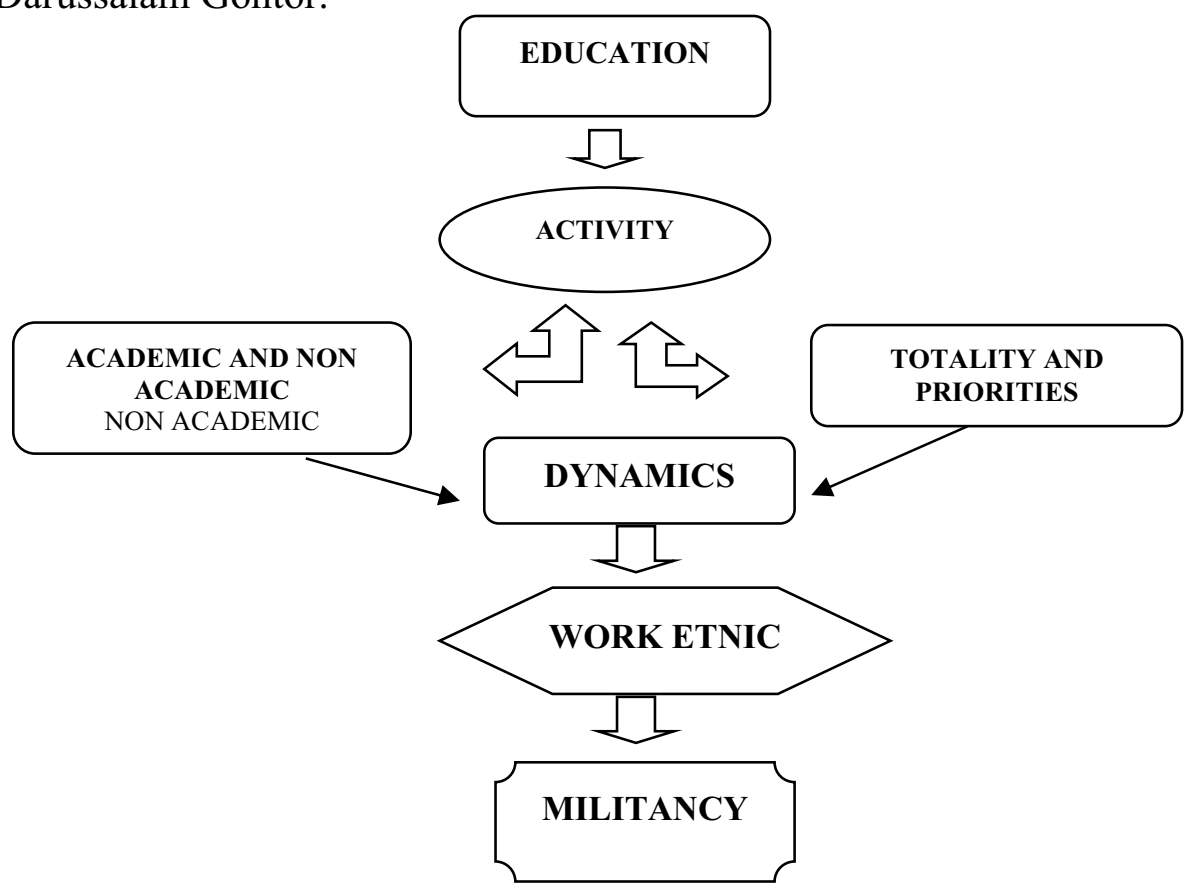

According Kyai Mashyudi Shobari, assignment in the management at this boarding school is the totality, although still with the control of clerics through staff parenting students, and in the organization instilled the motto "ready to lead and ready to led." 8 Totality is meant is that all administrators should know and be able to master the problems in

${ }^{7}$ Abdullah Syukri Zarkasyi, Management boarding school, Pondok Pesantren Modern Experience Gontor, (Ponorogo: Trimurti Press. 2005), p.82.

8 interview with director teacher Pesantren (Islamic Boarding) Gontor, home offices teacher, dated August 12, 2011 
their share and must coordinate with the other parts in every movement and step of the run, it is known in Pesantren (islamic boarding) with the term "no cutting". Based on the observation of the author that in this Pesantren (islamic boarding) all teachers, administrators, students must be ready to lead and be led, and here are already used to seeing the cleric also be a driver cabin, serving students meals and so forth ". concluded that the strategy of leadership style adopted by leader in carrying out character education program is strategy leadership style totality. Not the totality of the means of authoritarian and take the whole problem by yourself leader of his own that would tend to bring leadership to the model of a dictator, but it means that the leader must be willing and able to devote the time and his thoughts for the public interest above personal interests and family. Then the leaders strategy should also be able to identify and resolve all problems and solve them, either resolved itself or delegated to institutions under it.

The method used in the learning process implemented character education in Pesantren (islamic boarding) Darussalam Gontor.

Associated with the development strategy, there are some things that the way in coaching, which is not only intended for students but for anyone who is ruled by the method used Pesantren (islamic boarding). As for environment can be described as follows:

a. Learning through exemplary character.

According to Kyai Hasan Abdullah Sahal, that education is more embedded and transmitted informally; not just with lectures, briefings, upgrading, discussions, lectures, and the like. Precisely transformation is mostly done through learning by example and habituation, like going to the mosque and to class on time, training, care of the organization, participate in a dorm like committee that helped to organize, race and even accept any punishment given boarding schools as learning alive.

b. Students Learning Through Assignment character and upbringing.

One part of this institution is the institution staff nurture students who are directly under the command of the leadership of that particular cabin oversees the caring students in extra curricular activities, be it students juniors (students grades 1-6) and senior students (master). The institute is in charge of three students organizations: Organiztion of Student, Scouts and student Council who teach and guide the students to socialize with a community among themselves inside the Pesantren (islamic boarding), 
through the organization. Ranging from board dormitories, classrooms, organizations intra / extra, up to Scoutmaster that alternate every year, that's where they're used character honest as managing cooperative, polite and proper, humble in serving guests, take care of and nurture younger siblings, as well as reward appropriate for those who had been submissive to help any activity or organization or activity. Here is a chart of Figure 7 on the organizational structure in Pesantren (islamic boarding) Darussalam Gontor.

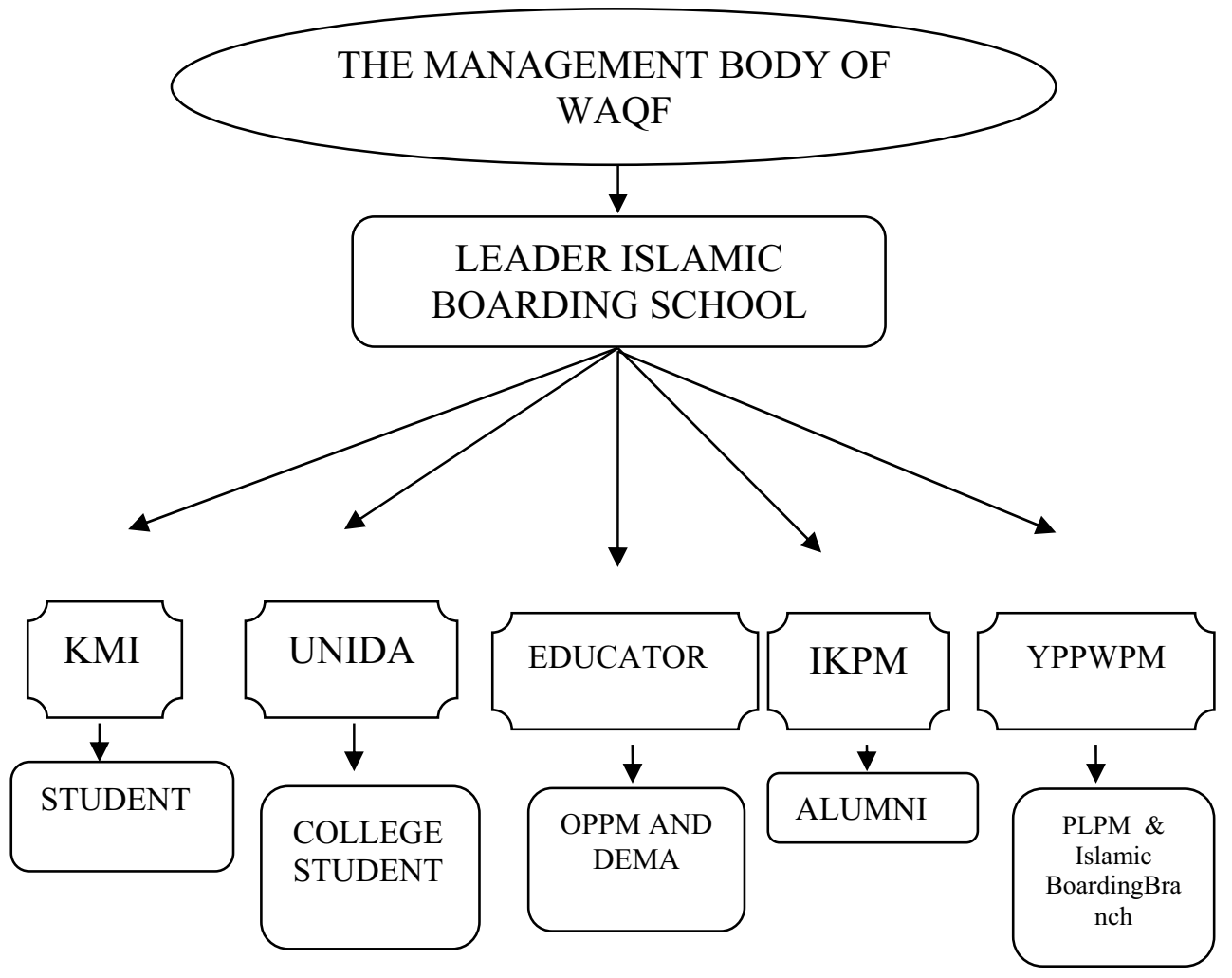

System dormitory (boarding), maintained since the Trimurti (founder of the lodge) until now, because in addition to not leave the typical boarding school, is also intended purposes and principles of education can be fostered and developed more efficiently and effectively, because the dormitory system is very supportive of creation " environmental engineering ", according to the reconstructionist philosophy into one theory used in this study. In connection with the 
achievement of the objectives and functioning of the education system, then the time in boarding arranged in an orderly manner.

c. Character Learning Through habituation

Entire students, without exception, have to get used to implement and apply all their knowledge in everyday life. All students are taught to get up early, morning prayers, wird, and sorogan in the morning. From morning until evening doing the learning activities together with teachers. Afternoons doing extra-curricular activities. All students are taught to pray in the mosque. To improve quality students in language, all students are taught to speak English and Arabic with any given day. The students who do not obey the rule will be invoked and heard by the council session that already selected. Value of report cards of students is not only determined by intelligence alone, but is also determined by the quality of the character and behavior of students daily.

\section{d. Character Learning Through Training Program}

Boarding Gontor have Central Training Institute management and community development (PLPM). Its activities are concentrated on the development and improvement of the quality of human resources to prepare for independence graduate and students in the development of society and business, so it can later serve in the community soon became independent preachers, build entrepreneurial spirit.

\section{e. Character Pupils learning through participation in a variety of} activities.

Co-curricular activities and extracurricular would be more meaningful if it is filled with a variety of beneficial activities for students that have a value of character education. With activities planned, programmed and tersistem. Each activity must be a supervisor to determine the direction of these activities will be implemented. The program is presented with a very attractive, involving technique of simulation, role play and discussion. On improving learning skills, learners acquire learning techniques, mind mapping, and technical reading. While thinking skills focused on improving problem solving skills, decision making. While living skills more emphasis on several things including self-management, build dream, techniques to communicate, manage conflict and manage time. 


\section{f. Learning character through the Awards and Punishment}

Punishment, namely the implementation of the consequences of violations committed by students who leave liability. Giving these penalties should be complemented with the award so that children feel appreciated and behavior. The target of this method is that do practicing responsibility in life.

\section{Character students resulting in Pesantren (islamic boarding) Darussalam Gontor.}

The purpose of Pesantren (islamic boarding) education is to create and develop character students or reflected in the motto islamic boarding school "become scholars of the intellect, not the intellect knows religion", ie the personality of faith and fear of God, noble, beneficial for the community is able to stand alone, independent and resolute in personality. Creation character education process as such, must necessarily be based on the awareness of the meaning of life and a life full of meaning. In schools given the view that life should be meaningful "live a meaningful life." Life would be meaningless if it can benefit others.

According to teacher Azhar Amir Zaen, that Kyai in islamic boarding school always advise to keep good relationships between people with and not always on the basis of material relations, but the inner relationship. In work and their knowledge is always oriented to the sincerity is what needs to be conserved in the islamic boarding school ${ }^{9}$.

\section{Barriers leader in implementing character education}

Based on observation and interview the author by leader boarding school, there are several obstacles, among others: the students are coming from all over Indonesia, even abroad who have a background in socioeconomic and require huge costs that require evaluation system stratified by the demands of the world and parents work towards graduate schools and then the influence of information technology, the Internet and other electronic equipment which have a negative effect on the character of students.

${ }^{9}$ Interview with teacher islamic boarding school Gontor, home offices teacher, dated August 15, 2011 


\section{Efforts are made Kyai in overcoming the problems/obstacles in the process of character education programs}

a. In addressing the diversity of background of prospective students, clerics prepare oreintasi program for new students. This activity is carried out by more senior students and teachers at the boarding school. The new students are introduced to the culture and character of Islamic practiced by senior students.

b. Pupils, with weak economic background, are given scholarships and introduced for internships and develop the business unit for the development of entrepreneurial spirit boarding.

c. Pupils are numerous, clerics makes program development and evaluation storied. It means that the authority of teachers, partly delegated to the senior students to foster a more junior students.

d. The presence of technology, information, internet, and other electronic equipment, prevented by the existence of a strict boarding school and designed program of strengthening of the soul and spirit of students.

e. Efforts to improve the competence of students, made internships and entrepreneurial activities that are expected to have an entrepreneurial spirit.

f. In order to avoid boredom, then clerics and teachers, designed a holiday program fairly and allow parents to visit their children.

g. High costs for the character education program, clerics can obtain from various sources, for example the development of the business units boarding schools, grants, zakat, waqf or other donor sources, including alumni of Pesantren (islamic boarding) Darussalam Gontor.

h. System leadership of this totality, a risk that must be borne by Kyai, especially in terms of dividing time between family 
interests and the interests of the foundation and the education of students, the clerics must develop the skills to develop the art of leadership, including the art of delegating tasks, can help clerics and teachers in organizing time and energy, so families can still unnoticed.

\section{F.Conclusions}

Based on the discussion above, this research resulted in several conclusions: leadership style in Pesantren (islamic boarding) Darussalam Gontor in order to hold the character education using religio-paternalistic leadership style in which the existence of a force of interaction between the clerics with the students based on religious values and Character education process lasts 24 hours. Where character education is built with an exemplary method, direction, habituation, training, participation, punishment and rewards. Because the clerics may not by it self set entirely, then leader should be able to build confidence in each students and teachers. And graduates desired character by the Pesantren (islamic boarding) Darussalam Gontor is the youth of Islam are not only strong in the 'science' of scientific but also in science to actualize (science 'amaliyah). Islamic boarding school School trying to print the future leaders capable of fighting in any field that is becoming the choice of characters armed with a strong believer competent and life skill that has been formed and able to fight with all the obstacles. Competencies students are expected to have knowledge and can be applied in life with high moral values. The main obstacles faced in implementing character education kyai include: the diversity of cultural backgrounds and socioeconomic,the number of students that many, a negative influence in the era of globalization and information technology, the demands of the world of work and the demands of the elderly and The amount to be provided. As for the solution by religious scholars / leaders boarding school in the face of obstacles and barriers in implementing character education by performing co-operation with the caregiver / administrators, teachers, students, the community and the government to keep doing activities / training, create an activity as a means to get accustomed to character well, always be an example for the citizens of the boarding school, without favoritism in giving punishment or reward that character education in accordance with the desired goals and expectations. 


\section{REFERENCE}

Dacholfany, M.Ihsan, 2014, Character Education Learning from Gontor ,Wafi Media Tama, Director General of Religious Affairs, 2009, Encyclopedia of Islam in Indonesia,

Effendi, 2008, .The Impact of Transformational Leadership Against Pesantren Educationn System in Jam'iyyah Persis, UIN Jakarta Hasbullah. 2005, Basic Education. Jakarta. Publisher: PT Persada RajaGrafindo.

Hashim, 1999, Looking Ulama Heir of the Prophets, Brief History of The Scholars. Surabaya: Bina Sciences.

Lickona, T., 1992, Educating for Character, How Our Schools Can Teach Respect and Responsibility, New York: Bantam Books.

Mahpuli, 2003, .Influence of Islamic School of Management in Formation of Human Resources, PPs UIN Bandung,

Majid, N., 1995, Chambers Islamic Boarding School: A Portrait Travel, Jakarta: Paramadina.

Murphy, J., 2002, The Secret Power of the Subconscious Mind, Jakarta, Spectrum.

Zamakhsyari, D., 1994, Islamic Boarding School Tradition: Studies Worldview Kyai, Jakarta: LP3ES.

Zarkasyi, K.H. AS 2005, Seminar Jakarta Design Center, Ponorogo: Trimurti Press.

Zarkasyi, K.H. USA, 2005, The Management boarding school, Pondok Modern Experience Gontor, Ponorogo: Trimurti Press. 